\title{
Retrograde Perfusion of the Cerebral Vein with Antioxidant L Y231617 Reduces Brain Damage in the Rat Focal Ischemia Model
}

\author{
Takeki NAGAO, Y. Lucas YAMAMOTO, Nobuhiro INOUE*, \\ and Yasushi ITO**
}

\begin{abstract}
Neuroisotope Laboratory and Cone Laboratory for Neurosurgical Research, Montreal Neurological Institute and McGill University, Montreal, Quebec, Canada; *Department of Neurosurgery, Kumamoto University School of Medicine, Kumamoto; ${ }^{* *}$ Department of

Neurosurgery, Brain Research Institute, Niigata University, Niigata
\end{abstract}

\begin{abstract}
Retrograde perfusion of the cerebral vein (RPCV) with antioxidant LY231617 was evaluated in the focal ischemia model in rats as a new therapeutic route to deliver cytoprotective agents more selectively and efficiently into ischemic brain tissue. Thirty-six Sprague-Dawley rats were divided into Groups A through D. Focal ischemia was induced for 3 hours in the rats, then all groups were treated differently for 2 hours and then sacrificed. Rats in Group A $(n=10)$ served as the control group and was left untreated. Rats in Group B $(\mathrm{n}=10)$ received an intravenous infusion of LY231617 (10 mg/ $\mathrm{kg} / \mathrm{hr})$. Rats in Group C $(n=6)$ received saline $(86 \mu \mathrm{l} / \mathrm{min})$ through RPCV. Rats in Group D $(\mathrm{n}=10)$ received LY231617 $(10 \mathrm{mg} / \mathrm{kg} / \mathrm{hr})$ in saline $(86 \mu \mathrm{l} / \mathrm{min})$ through RPCV. The regional cerebral blood flow (rCBF) was measured using $\left[{ }^{14} \mathrm{C}\right]$ iodoantipyrine autoradiography, and phorbol 12,13-dibutyrate (PDBu) binding by in vitro $\left[{ }^{3} \mathrm{H}\right] \mathrm{PDBu}$ autoradiography. Ischemic brain damage was assessed quantitatively after staining with cresyl violet and Luxol fast blue. Rats in Group D showed significantly higher $\mathrm{rCBF}(41-400 \%, \mathrm{p}<0.05)$ in the ischemic cortical and subcortical areas, and a significant reduction $(66 \%, \mathrm{p}<0.01)$ in the total volume of ischemic damage and reduction of $\mathrm{PDBu}$ binding $(\mathrm{p}<0.05)$ in the lateral striatum of the ischemic hemisphere, as compared to the rats in Groups A-C. RPCV with antioxidant LY231617 achieves a more beneficial effect on focal ischemic tissue than regular systemic administration.
\end{abstract}

Key words: ischemic brain damage, phorbol-dibutyrate binding, retrograde perfusion, cerebral vein, antioxidant, cerebral blood flow

\section{Introduction}

Experimental studies of ischemic brain injury have demonstrated a direct relationship between excess production of free radicals ${ }^{3,15,16,21,36,37)}$ and the release of excitatory amino acids which are induced in a series of molecular events linked to ischemic neuronal cell death..$^{27,30)}$ Experimental data have also indicated that various free radical scavengers or antioxidants significantly reduce damage induced by ischemia. $1,2,7,9,13,17,19,22,32,45)$ However, systemic administration of free radical scavengers or antioxidants was only of benefit if started before or shortly after the onset of cerebral ischemia. $1,2,7,9,13,17.19,22.32$ ) Therefore, the time window for effective systemic administration of these agents is too narrow.

We previously developed a method of retrograde perfusion of the cerebral vein (RPCV) for delivering a cytoprotective agent into ischemic tissue via a cerebral vein. ${ }^{14,42,43,46)}$ The cerebral veins have no valves, undergo minimal atherosclerotic changes, ${ }^{38,39)}$ and are provided with rich micro-collateral chan-

Received February 13, 1995; Accepted June 16, 1995

Author's present address: T. Nagao, M.D., Department of Neurosurgery, Neurological Institute, Tokyo Women's Medical College, Tokyo, Japan. 


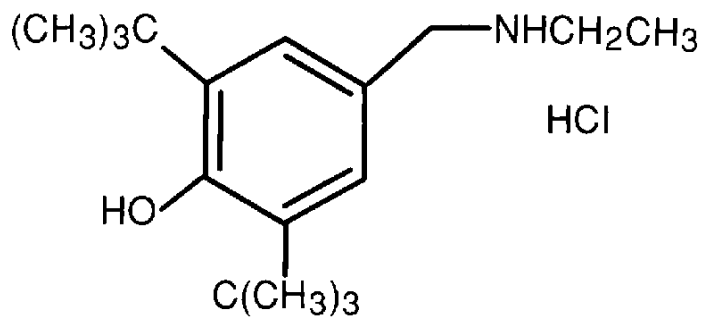

Fig. 1 Chemical structure of antioxidant LY231617.

nels. ${ }^{47}$ RPCV is a more selective and efficient delivery route into the ischemic tissue than regular systemic administration. ${ }^{42,43)}$ Our recent study showed that RPCV of the calcium channel blocker verapamil achieved a significant improvement in ischemic brain in the focal ischemia for 3 hours in rats. ${ }^{14)}$

The new antioxidant LY231617 (2,6-bis(1,1dimethylethyl)-4-[(1-ethyl)amino]methylphenol hydrochloride, Fig. 1) inhibits iron-dependent lipid peroxidation and blocks a key enzyme activity, that of the arachidonic acid cascade. ${ }^{8,9)}$ In addition, this drug easily penetrates the blood-brain barrier and produces a vasodilating effect. ${ }^{9)}$

The present study compared the therapeutic efficacy of RPCV with systemic administration of LY231617 $(10 \mathrm{mg} / \mathrm{kg} / \mathrm{hr})$ using the focal cerebral ischemia model in rats. The effectiveness of the treatment was evaluated by quantitative double-tracer autoradiography with $\left[{ }^{14} \mathrm{C}\right]$ iodoantipyrine (IAP) to measure regional cerebral blood flow (rCBF) ${ }^{35)}$ and $\left[{ }^{3} \mathrm{H}\right]$ phorbol 12,13-dibutyrate (PDBu) to measure the activity of $\mathrm{PDBu}$ binding. ${ }^{28,44)}$ The volume of ischemic damaged tissue was also measured using a modified method of Osborne et al. ${ }^{29)}$

\section{Materials and Methods}

The focal ischemia model was prepared in 36 Sprague-Dawley rats. Details of the surgical preparation and monitoring of physiological parameters have been previously published. ${ }^{14,42,43)}$ In brief, anesthesia was induced through inhalation of $2.0-$ $2.5 \%$ halothane for 3-5 minutes and maintained by spontaneous respiration of $0.5-1.0 \%$ halothane in room air through a mask. Polyethylene catheters were placed in the femoral artery for the monitoring of blood pressure, blood gases, hematocrit, blood glucose concentration, and radioisotope content, and in the femoral vein for administration of radioisotopic tracers and drugs. A small craniectomy was made in the left subtemporal region with a dental drill. After electrocoagulation of all len- ticulostriate branches of the middle cerebral artery (MCA) under a microscope, the left MCA was occluded by a Zen clip (Ohwa Tsusho Ltd., Tokyo) proximal to the lateral striate arteries, using a modified method of Tamura et al. ${ }^{14,41)}$ The MCA remained occluded by the clip until decapitation. After occlusion of the left MCA, a small craniectomy was performed at the left inferior posterior part of the squamosal bone for the cannulation of the inferior cerebral vein in rats used for RPCV. A tapered PE-10 polyethylene catheter was cannulated backwards into the inferior cerebral vein. After completion of the surgical procedure, all rats were immobilized using loose-fitting plaster casts, and halothane was discontinued to remove the effect of general anesthesia. All rats recovered completely from general anesthesia at least 1 hour before decapitation. Lidocaine hydrochloride was used for local anesthesia of the surgical wounds during the experiments.

Three hours after occlusion of the MCA, the rats were divided into four groups. Rats in Group A $(\mathrm{n}=10)$ served as the control group and received no agents. Rats in Group $B(n=10)$ received an intravenous infusion of LY231617 $(10 \mathrm{mg} / \mathrm{kg} / \mathrm{hr})$ (Lilly Research Laboratories, Eli Lilly and Co., Indianapolis, Ind., U.S.A.) in saline $(86 \mu \mathrm{l} / \mathrm{min})$ into the femoral vein. Rats in Group $C(n=6)$ received saline $(86 \mu \mathrm{l} / \mathrm{min})$ through $\mathrm{RPCV}$, and rats in Group $\mathrm{D}(\mathrm{n}=10)$ received LY231617 $(10 \mathrm{mg} /$ $\mathrm{kg} / \mathrm{hr})$ in saline $(86 \mu \mathrm{l} / \mathrm{min})$ through $\mathrm{RPCV}$, both through the inferior cerebral vein. The saline was delivered using an infusion pump over a period of 2 hours. During the 2 hours of RPCV, the infusion pressure of LY231617 solution was kept constant at $150 \mathrm{mmHg} .{ }^{39)}$ The body temperature was maintained at $37 \pm 0.5^{\circ} \mathrm{C}$ with a heating lamp. Systemic blood pressure and blood gases were checked regularly and maintained within physiological ranges. Hematocrit and blood glucose concentration were determined intermittently using arterial blood samples.

Four hours and 59 minutes after occlusion of the left MCA, all rats received an injection in the femoral vein of $\left[{ }^{14} \mathrm{C}\right] \mathrm{IAP}(30 \mu \mathrm{Ci})$ (DuPont Canada Inc., Mississauga, Ontario, Canada; specific activity $50 \mathrm{mCi} / \mathrm{mmol})$ in normal saline $(1 \mathrm{ml})$ over a period of 1 minute. A $20 \mu \mathrm{l}$ arterial blood sample was drawn every 5 seconds during injection of the tracer to determine the ${ }^{14} \mathrm{C}$ radioactivity in the arterial plasma. The animals were decapitated 1 minute after the start of $\left[{ }^{14} \mathrm{C}\right]$ IAP infusion. The brains were quickly removed and frozen in liquid Freon-12 (Histo Freeze, Fisher Scientific Co., Pittsburgh, Pa., U.S.A.). The frozen 
brains were sliced into $20 \mu \mathrm{m}$ thick sections by a cryostat $\left(-22^{\circ} \mathrm{C}\right)$. The sections were mounted on a microscopic slide and rapidly dried on a hot plate for autoradiography. Alternate sections were used for $\left[{ }^{14} \mathrm{C}\right] \mathrm{IAP}$ and $\left[{ }^{3} \mathrm{H}\right] \mathrm{PDBu}$ autoradiography experiments.

The brain sections for $\left[{ }^{14} \mathrm{C}\right]$ IAP autoradiography were exposed to Kodak SB-5 films (Rochester, N.Y., U.S.A.) for 1 week with Carbon-14 Standards (American Radiolabeled Chemicals Inc., St. Louis, Mo., U.S.A.). Densitometric measurements of the autoradiograms were performed with a digital image analyzer (The Image Calculator; McGill University, Montreal, Canada). Mean values for the ${ }^{14} \mathrm{C}$ tissue radioactivities were obtained by measuring the optical density on autoradiograms of the same locus on three consecutive brain slices as designated by the rat brain atlas. rCBF was calculated using the operational equation of Sakurada et al. ${ }^{35)}$ A tissue-blood partition coefficient of 0.8 was used.

PDBu binding activity was determined by the in vitro receptor binding method using $\left[{ }^{3} \mathrm{H}\right] \mathrm{PDBu}$ autoradiography of Worley et al. ${ }^{44)}$ and Onodera et $a l{ }^{283}$ in Groups A, B, and D. The slices were divided into two groups: one for $\left[{ }^{3} \mathrm{H}\right] \mathrm{PDBu}$ autoradiography and the other for the verification of $\left[{ }^{14} \mathrm{C}\right] \mathrm{CAP}$ washout. All slices were mounted on gelatin-coated microscopic slides and soaked twice in ice cold buffer $(50 \mathrm{mM}$ Tris $\mathrm{HCl} / \mathrm{pH} 7.7,100 \mathrm{mM} \mathrm{NaCl}, 1 \mathrm{mM}$ $\mathrm{CaCl}_{2}$ ) for 5 minutes to reduce the $\left[{ }^{14} \mathrm{C}\right] \mathrm{IAP}$ activity to less than $1 \%$. The slices for $\left[{ }^{3} \mathrm{H}\right] \mathrm{PDBu}$ autoradiography were incubated in $25^{\circ} \mathrm{C}$ buffer with $2.5 \mathrm{nM}\left[{ }^{3} \mathrm{H}\right] \mathrm{PDBu}$ (DuPont Canada Inc.; specific activity $20 \mathrm{Ci} / \mathrm{mmol}$ ) for 1 hour, washed twice in ice cold buffer for 2 minutes, and then briefly rinsed in ice cold distilled water. Preliminary experiments verified that specific $\left[{ }^{3} \mathrm{H}\right] \mathrm{PDBu}$ binding reached a plateau during these incubation periods. Nonspecific labeling was assessed by adding $1 \mu \mathrm{M}$ PDBu to the incubation solution. All specimens were imme- diately dried under a stream of cold air and exposed to Hyperfilm- ${ }^{3} \mathrm{H}$ (Amersham, Arlington Heights, III., U.S.A.) for 1 week with Tritium Standards (American Radiolabeled Chemicals Inc.). Densitometric measurements of the autoradiograms were performed in the same manner as for $\left[{ }^{14} \mathrm{C}\right]$ IAP autoradiography. Optical densities of $\left[{ }^{3} \mathrm{H}\right] \mathrm{PDBu}$ binding were measured and converted to $\mathrm{fmol} / \mathrm{mg}$ tissue based on the values for the Tritium Standards.

Measurement of the volume of ischemic brain used frozen coronal tissue sections of $20 \mu \mathrm{m}$ thickness obtained from the areas adjacent to those used for the autoradiographic studies. The most posterior coronal section was taken $3.2 \mathrm{~mm}$ anterior to the occipital pole, and six more sections were taken at 1.28 $\mathrm{mm}$ intervals toward the anterior side. These sections were then fixed in 10\% formaldehyde solution for over 24 hours and stained by a combined method of cresyl violet and Luxol fast blue. ${ }^{14,29)}$ The unstained ischemic areas were manually outlined on the digitized images of these sections with a digital image analyzer (The Image Calculator). Any indistinct border of an ischemic area was verified under light microscopic examination for neuronal ischemic damage. ${ }^{29)}$ The total volume of early ischemic brain damage was determined by the integration of the seven areas with the distance between neighboring sections.

All data were expressed as mean $\pm \mathrm{SD}$. The statistical analysis of all data was performed using a one-way analysis of variance, followed by Tukey's intergroup comparison test. A p-value of $<0.05$ was considered significant.

\section{Results}

There were no significant differences in blood pressure, blood gases, body temperature, hematocrit, and blood glucose concentrations during

Table 1 Physiological variables during experiments

\begin{tabular}{lcccc}
\hline & Group A (n=10) & Group B (n=10) & Group C (n=6) & Group D (n=10) \\
\hline $\mathrm{MABP}(\mathrm{mmHg})$ & $122 \pm 6$ & $124 \pm 8$ & $118 \pm 6$ & $120 \pm 10$ \\
$\mathrm{PaCO}_{2}$ (torr) & $40.7 \pm 4.1$ & $42.1 \pm 4.7$ & $41.2 \pm 5.3$ & $42.3 \pm 3.9$ \\
$\mathrm{PaO}_{2}$ (torr) & $100 \pm 7$ & $107 \pm 12$ & $109 \pm 10$ & $105 \pm 13$ \\
$\mathrm{pH}$ & $7.41 \pm 0.05$ & $7.41 \pm 0.03$ & $7.39 \pm 0.02$ & $7.40 \pm 0.03$ \\
$\mathrm{Ht}(\%)$ & $46.4 \pm 0.9$ & $45.6 \pm 1.6$ & $45.5 \pm 1.7$ & $45.6 \pm 1.7$ \\
$\mathrm{Temp}(\mathrm{C})$ & $37.0 \pm 0.2$ & $37.1 \pm 0.3$ & $37.1 \pm 0.1$ & $37.0 \pm 0.4$ \\
$\mathrm{BG}(\mathrm{mg} / \mathrm{dl})$ & $188 \pm 35$ & $166 \pm 37$ & $173 \pm 28$ & $177 \pm 19$ \\
\hline
\end{tabular}

All values are mean \pm SD. BG: plasma glucose level, Ht: hematocrit, MABP: mean arterial blood pressure, Temp: body temperature. 
Table 2 Changes of $\mathrm{rCBF}$ in rats

\begin{tabular}{|c|c|c|c|c|c|c|c|c|}
\hline \multirow{2}{*}{ Structure } & \multicolumn{2}{|c|}{ Group A $(\mathrm{n}=10)$} & \multicolumn{2}{|c|}{ Group B $(n=10)$} & \multicolumn{2}{|c|}{ Group C $(n=6)$} & \multicolumn{2}{|c|}{ Group D $(n=10)$} \\
\hline & Left & Right & Left & Right & Left & Right & Left & Right \\
\hline Frontal cort & $71 \pm 17$ & $163 \pm 27$ & $82 \pm 20$ & $163 \pm 23$ & $65 \pm 19$ & $168 \pm 27$ & $100 \pm 22^{\ddagger}$ & $171 \pm 21$ \\
\hline Sensorimot & $18 \pm 16$ & $139 \pm$ & & & & & & $=23$ \\
\hline Anterior $\mathrm{p}$ & $15 \pm 18$ & $133 \pm 23$ & $10 \pm 18$ & $139 \pm$ & $18 \pm 12$ & $163 \pm$ & $47 \pm 18^{H}$ & $148 \pm 19$ \\
\hline Posterior parietal cortex & $19 \pm 24$ & $136 \pm 20$ & $5 \pm 6$ & $136 \pm$ & $20 \pm$ & $160 \pm$ & $18^{*}$ & $141 \pm 20$ \\
\hline Lateral caudate & $13 \pm 17$ & $140 \pm$ & $42=$ & $141 \pm$ & $20 \pm 24$ & $134=$ & $57 \pm 29^{*}$ & $134 \pm 19$ \\
\hline Medial caudate & $54 \pm 27$ & $133 \pm 27$ & $75 \pm 38$ & $132 \pm 19$ & $58 \pm 11$ & $128 \pm 31$ & $109 \pm 20^{\ddagger}$ & $132 \pm 19$ \\
\hline $\begin{array}{l}\text { Posterolateral portion of } \\
\text { caudo-putamen }\end{array}$ & $13 \pm 13$ & $123 \pm 18$ & $34 \pm 29$ & $127 \pm 16$ & $18 \pm 16$ & $123 \pm 25$ & $65 \pm 32^{\ddagger}$ & $120 \pm 20$ \\
\hline
\end{tabular}

All values are mean $\pm \mathrm{SD}(\mathrm{ml} / 100 \mathrm{~g} / \mathrm{min}) .{ }^{*} \mathrm{p}<0.05$, significant difference from Group $\mathrm{A} .{ }^{\ddagger} \mathrm{p}<0.05$, significant difference from Groups A and C. ${ }^{4} \mathrm{p}<0.05,{ }^{p \# p} \mathrm{p}<0.01$, significant difference from Groups A-C.

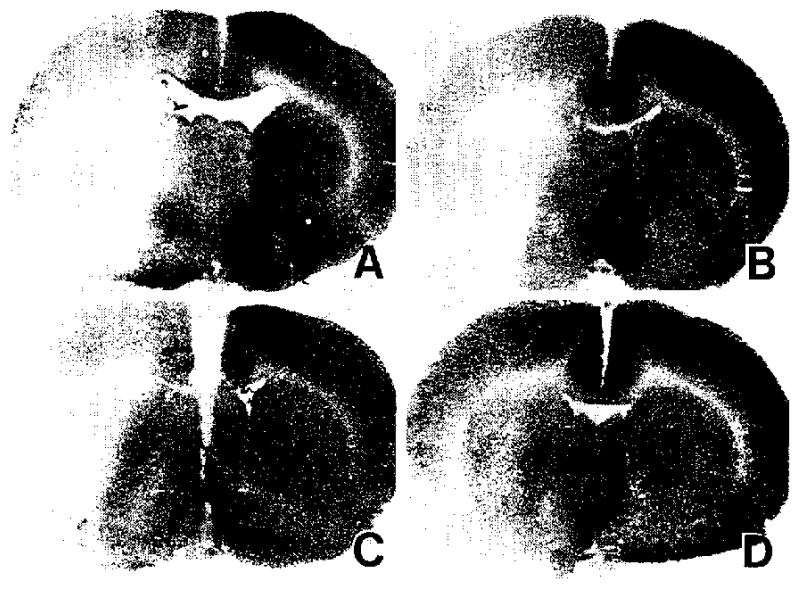

Fig. 2 Autoradiograms of $\left[{ }^{14} \mathrm{C}\right] \mathrm{IAP}$ in the coronal section of the sensorimotor cortex and in the region of the caudate nucleus. Group D rats (D) showed a marked improvement of rCBF compared to rats in Groups A (A), B (B), and $\mathrm{C}(\mathrm{C})$.

transvenous retrograde perfusion of the brain and administration of LY231617 between the groups of rats (Table 1).

The rCBF in Groups B and C showed no significant difference compared to Group A (Table 2). In Group $D, \quad r C B F$ increased significantly in the ischemic cerebral cortices (frontal cortex: $41 \%$, p < 0.05 ; sensorimotor cortex: $233 \%, \mathrm{p}<0.01$; anterior parietal cortex: $213 \%, \mathrm{p}<0.05$; posterior parietal cortex: $168 \%, \mathrm{p}<0.05$ ) and in the ischemic subcortical areas (caudate nucleus: 220\%, p < 0.05 ; posterolateral portion of caudo-putamen: $400 \%$, $\mathrm{p}<0.05$ ) compared to the corresponding areas of Group A (Table 2). Figure 2 shows representative autoradiograms for all groups.

$\left[{ }^{3} \mathrm{H}\right] \mathrm{PDBu}$ binding in the ischemic area of Groups $\mathrm{A}$ and $\mathrm{B}$ was $12-24 \%$ higher than the homologous area of the non-ischemic hemisphere (Table 3). In Group $\mathrm{D},\left[{ }^{3} \mathrm{H}\right] \mathrm{PDBu}$ binding in the ischemic area was similar to the homologous area of the nonischemic hemisphere (Table 3). [ $\left.{ }^{3} \mathrm{H}\right] \mathrm{PDBu}$ binding in the posterolateral portion of the caudo-putamen of the ischemic hemisphere of Group $D$ was reduced significantly $(34-39 \%, p<0.05)$ compared to Groups A and B. $\left[{ }^{3} \mathrm{H}\right] \mathrm{PDBu}$ in the remainder of the ischemic hemisphere of Group D was moderately reduced $(16-35 \%)$, but not significantly, compared to Groups A and B (Table 3). Figure 3 shows representative autoradiograms for all groups.

The volume of ischemic brain damage in Groups B and $C$ showed no significant difference compared to Group A (Table 4). Group D rats showed a reduction of $66 \%$ in the total volume of ischemic damaged tissue $(\mathrm{p}<0.01$ ) compared to Group A (Table 4 ). The area of ischemic damaged tissue was reduced significantly at the sensorimotor level $(69 \%, p<$ $0.05)$ and the parietal level $(59 \%, p<0.05)$ compared to Group A (Table 4).

\section{Discussion}

The inferior cerebral vein in rats, which collects venous blood from the centroparietal temporal regions, ${ }^{4)}$ can be used as a retrograde route to deliver cytoprotective agents to ischemic brain tissue. The cerebral vein can tolerate up to $150 \mathrm{mmHg}$ retrograde perfusion pressure, without any change in blood-brain barrier permeability. ${ }^{43)}$ Our previous study demonstrated that RPCV, with the calcium channel blocker verapamil, resulted in a significant increase of $\mathrm{rCBF}$ in the ischemic cerebral cortices 
Table 3 Concentration of $\left[{ }^{3} \mathrm{H}\right] \mathrm{PDBu}$ binding in rats

\begin{tabular}{|c|c|c|c|c|c|c|}
\hline \multirow{2}{*}{ Structure } & \multicolumn{2}{|c|}{ Group A $(n=10)$} & \multicolumn{2}{|c|}{ Group B $(n=10)$} & \multicolumn{2}{|c|}{ Group D $(n=10)$} \\
\hline & Left & Right & Left & Right & Left & Right \\
\hline Sensorimotor cortex & $843 \pm 263$ & $751 \pm 265$ & $927 \pm 252$ & $782 \pm 241$ & $709 \pm 150$ & $722 \pm 293$ \\
\hline Anterior parietal cortex & $1078 \pm 471$ & $956 \pm 427$ & $970 \pm 217$ & $797 \pm 156$ & $704 \pm 265$ & $723 \pm 218$ \\
\hline Lateral caudate & $925 \pm 296$ & $780 \pm 263$ & $911 \pm 217$ & $733 \pm 182$ & $700 \pm 184$ & $741 \pm 267$ \\
\hline Posterolateral portion of caudo-putamen & $1178 \pm 559$ & $1027 \pm 441$ & $1079 \pm 247$ & $875 \pm 173$ & $713 \pm 227^{\dagger}$ & $717 \pm 297$ \\
\hline
\end{tabular}

All values are mean $\pm \mathrm{SD}(\mathrm{fmol} / \mathrm{mg}) .{ }^{\dagger} \mathrm{p}<0.05$, significant difference from Groups A and $\mathrm{B}$.

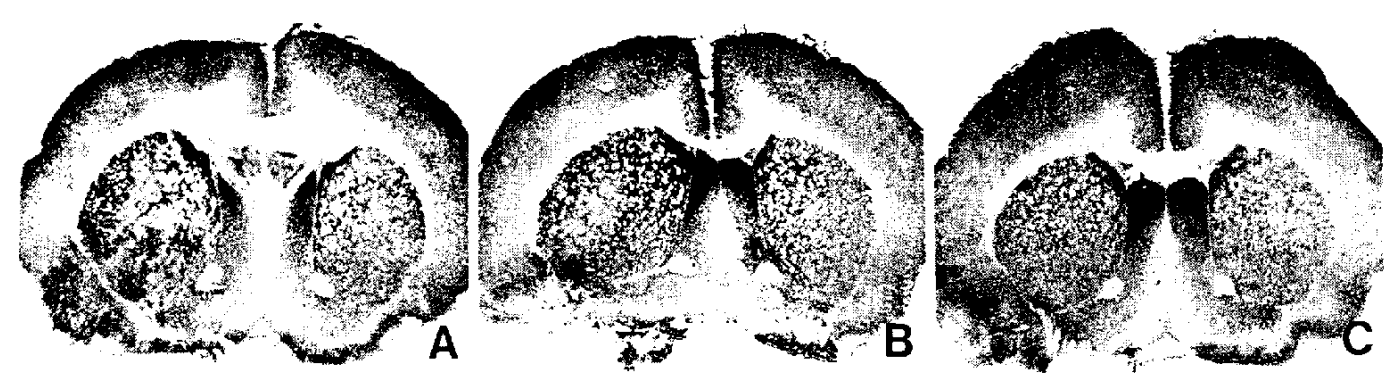

Fig. 3 Autoradiograms of $\left[{ }^{3} \mathrm{H}\right] \mathrm{PDBu}$ binding in the coronal section of sensorimotor cortex and caudate nucleus region. Rats in Group D (C) showed a significant reduction (34-39\%) of PDBu binding in the ischemic lateral caudate nucleus compared to rats in Groups A (A) and B (B).

Table 4 Changes in area and volume of ischemic damage in the ischemic hemisphere

\begin{tabular}{|c|c|c|c|c|}
\hline Distance from occipital lobe & Group A $(n=10)$ & Group B $(\mathrm{n}=10)$ & Group C $(n=6)$ & Group D $(n=10)$ \\
\hline $9.56 \mathrm{~mm}$ (frontal cortex, $\mathrm{mm}^{2}$ ) & $15.6 \pm 7.8$ & $9.8 \pm 5.2$ & $12.8 \pm 4.2$ & $4.9 \pm 2.8^{*}$ \\
\hline $8.28 \mathrm{~mm}$ (sensorimotor cortex, $\mathrm{mm}^{2}$ ) & $23.2 \pm 8.5$ & $15.8 \pm 7.7$ & $19.2 \pm 6.7$ & $7.2 \pm 3.2^{\ddagger}$ \\
\hline $7.00 \mathrm{~mm}$ (anterior parietal cortex, $\mathrm{mm}^{2}$ ) & $18.3 \pm 6.1$ & $18.1 \pm 8.3$ & $17.0 \pm 5.1$ & $7.8 \pm 2.7^{\dagger}$ \\
\hline $5.72 \mathrm{~mm}$ (posterior parietal cortex, $\mathrm{mm}^{2}$ ) & $13.4 \pm 3.3$ & $15.0 \pm 6.4$ & $12.6 \pm 3.0$ & $5.3 \pm 3.1^{f}$ \\
\hline Total damaged volume $\left(\mathrm{mm}^{3}\right)$ & $106.1 \pm 26.3$ & $99.7 \pm 35.6$ & $104.0 \pm 24.2$ & $36.6 \pm 9.2^{H \#}$ \\
\hline
\end{tabular}

All values are mean $\pm \mathrm{SD} .{ }^{*} \mathrm{p}<0.01$, significant difference from Group $\mathrm{A} .{ }^{\dagger} \mathrm{p}<0.01$, significant difference from Groups A and B. ${ }^{\ddagger} \mathrm{p}<0.05$, significant difference from Groups $A$ and $C$. " $p<0.05$, ${ }^{A \# p}<0.01$, significant difference from Groups A-C.

and subcortical areas, with a reduction of ischemic damaged tissue in these areas. ${ }^{14)}$ We also obtained similar results using a bypass between an extracerebral artery and a cerebral vein for retrograde verapamil infusion into the focal ischemic tissue without any increase of the superior sinus pressure in rats. ${ }^{46)}$ The present study showed that RPCV with LY231617 achieved a significant improvement in both $\mathrm{rCBF}$ and ischemic damaged tissue in the rat focal ischemia model. These findings strongly suggested that RPCV enhanced the therapeutic effect of the cytoprotective agents although direct comparison of the effect on cerebral ischemia between the cytoprotective agents cannot be made.

Oxygen radicals cause brain edema ${ }^{3,19,45)}$ and pronounced vascular effects, including increased vascular permeability and endothelial injury. ${ }^{16,18,36,37)}$ Furthermore, oxygen free radicals present endothelium-dependent relaxation by endotheliumderived relaxing factor, which has recently been identified as either nitric oxide or a closely related compound. ${ }^{11,23,24,26,33,34)}$ Lipid peroxidation and the arachidonic acid cascade also cause aberrant vascular reactions. ${ }^{16,36,37)}$ These harmful effects to the cerebral vessels result in decreased $\mathrm{CBF}$ and brain edema. Beneficial effects of free radical scavengers 
on CBF have been demonstrated in ischemia models. ${ }^{7,13,22,25)}$ The favorable effect of antioxidants on CBF is achieved by direct action upon endothelium and smooth muscle, and also by a reduction of brain edema. ${ }^{1,19,45)}$ Evidence from several experiments indicates that the phorbol ester receptor is identical to protein kinase $\mathrm{C}$ (PKC) ${ }^{6,26,28,44)}$ The activity of PKC can be assessed by binding of the phorbol ester receptor ligand $\left[{ }^{3} \mathrm{H}\right] \mathrm{PDBu}{ }^{44)}$ Activation of PKC causes contraction of the arterial smooth muscle,,$^{20,40)}$ which also affects CBF. In the early phase of biochemical events occurring during cerebral ischemia, $\mathrm{PKC}$ is activated by diacylglycerol and is important in the postischemic modulation of neuronal cell death. Excitatory amino acids activate the phosphatidylinositol cycle through the activation of phospholipase $\mathrm{C}$ resulting in generation of diacylglycerol which activates $\mathrm{PKC},{ }^{12)}$ and also activate the arachidonic acid cascade system. ${ }^{10)}$ Pellegrini-Giampietro et al. have reported that exogenously generated free radicals increase the release of excitatory amino acids from rat hippocampal slices, ${ }^{30,31)}$ and that various free radical scavengers reduced in vitro ischemia-induced excitatory amino acids release. ${ }^{31)}$

Our study revealed that PDBu binding in the ischemic area of untreated rats was increased by $12-$ $19 \%$, as compared to the homologous area in the non-ischemic hemisphere. RPCV with LY231617 reduced the $\mathrm{PDBu}$ binding in the ischemic hemisphere significantly compared to the ischemic hemisphere in untreated and systemically treated rats. In addition, the $\mathrm{PDBu}$ binding values in the ischemic lateral caudate nucleus revealed no significant difference from the non-ischemic hemispheres of all rats. LY231617 may restrain the vicious circle between free radicals and excitatory amino acids as mentioned above. A recent study has also indicated that LY231617 is effective in reducing damage in the hippocampal CA1 subfield in rats subjected to 30 minutes of four-vessel occlusion with reperfusion.")

Our present results indicate that RPCV delivery of the antioxidant LY231617 provides significant reduction of tissue damage in the 3-hour focal ischemia rat model, which is not achieved through regular intravenous administration of LY231617.

\section{Acknowledgments}

The authors thank Mrs. Janet Arts for her technical assistance and Ms. Louise Sabaz for her secretarial help.

This research was supported by MRC (MT-3174 and UI-11096) and Lilly Research Laboratories, Eli
Lilly and Co.

\section{References}

1) Abe K, Yuki S, Kogure K: Strong attenuation of ischemic and postischemic brain edema in rats by a novel free radical scavenger. Stroke 19: 480-485, 1988

2) Araki N, Greenberg JH, Uematsu D, Sladky JT, Reivich M: Effect of superoxide dismutase on intracellular calcium in stroke. $J$ Cereb Blood Flow Metab 12: 43-52, 1992

3) Asano $T$, Koide $T$, Gotoh $\mathbf{O}$, Joshita $H$, Hanamura $\mathrm{T}$, Shigeno $\mathrm{T}$, Takakura $\mathrm{K}$ : The role of free radicals and eicosanoids in the pathogenetic mechanism underlying ischemic brain edema. Mol Chem Neuropathol 10: 101-133, 1989

4) Bär $T$, Scheck $T$ : The vascular system of the rat cerebral cortex. Basic pattern of leptomeningeal vessels and numerical densities of neocortical arteries and veins, in Auer LM, Leon F (eds): An Experimental Clinical Update, The Cerebral Veins. New York, Springer, 1983, pp 65-71

5) Barsan WG, Brott TG, Olinjer CP, Marler JR: Early treatment for acute ischemic stroke. Ann Intern Med 111: 449-451, 1989

6) Castagna M, Takai $Y$, Kaibuchi K, Sano K, Kikkawa U, Nishizuka Y: Direct activation of calcium-activated, phospholipid-dependent protein kinase by tumor-promoting phorbol esters. I Biol Chem 257: 7847-7851, 1982

7) Cerchiari EL, Hoel TM, Safar P, Sclabassi RJ: Protective effects on combined superoxide dismutase and deferoxamine on recovery of cerebral blood flow and function after cardiac arrest in dogs. Stroke 18: 869878,1987

8) Clemens JA, Ho PK, Panetta JA: LY178002 reduces rat brain damage after transient global forebrain ischemia. Stroke 22: 1048-1052, 1991

9) Clemens JA, Saunders RD, Ho PP, Panetta JA: The antioxidant, LY231617, reduces global ischemic neuronal injury in rats. Stroke 24: 716-723, 1993

10) Dumuis A, Sebben $M$, Haynes L, Pin JP, Bockaert J: NMDA receptors activate the arachidonic acid cascade system in striatal neurons. Nature 336: 6873, 1988

11) Faraci FM, Brian JE: Nitric oxide and the cerebral circulation. Stroke 25: 692-703, 1994

12) Farooqui AA, Horrocks LA: Excitatory amino acid receptors, neural membrane phospholipid metabolism and neurological disorders. Brain Res Brain Res Rev 16: 171-191, 1991

13) Hall ED, Yonkers PA: Attenuation of postischemic cerebral hypoperfusion by the 21-aminosteroid U74006F. Stroke 19: 340-344, 1988

14) Hosaka T, Yamamoto YL, Diksic M: Efficacy of retrograde perfusion of the cerebral vein with verapamil after focal ischemia in rat brain. Stroke 22: 
$1562-1566,1991$

15) Kogure K, Arai H, Abe K, Nakano M: Free radical damage of the brain following ischemia, in Kogure K, Hossmann KA, Siesjö BK, Welsh FA (eds): Progress in Brain Research, vol 63. New York, Elsevier, 1985, pp 237-259

16) Kontos HA: Oxygen radicals in cerebral ischemia, in Ginsberg MD, Dietrich WD (eds): 16th Princeton Conferences, Cerebrovascular Diseases. New York, Raven Press, 1989, pp 365-371

17) Lesiuk $H$, Sutherland $G$, Peeling J, Butler $K$, Saunders J: Effect of U74006F on forebrain ischemia in rats. Stroke 22: 896-901, 1991

18) Lo WD, Betz AL: Oxygen free-radical reduction of brain capillary rubidium uptake. J Neurochem 46: 394-397, 1986

19) Martz D, Beer M, Betz AL: Dimethylthiourea reduces ischemic brain edema without affecting cerebral blood flow. I Cereb Blood Flow Metab 10: 352-357, 1990

20) Matsui T, Takuwa $Y$, Joshita $H$, Yamashita $K$, Asano T: Possible role of protein kinase C-mediated smooth muscle contractile system associated with occurrence of chronic vasospasm. J Cereb Blood Flow Metab 11: 143-149, 1991

21) McCord JM; Oxygen-derived free radicals in postischemic tissue injury. $N$ Engl J Med 312: 159163, 1985

22) Meyer FB, Sundt TM, Yanagihara T, Anderson RE: Focal cerebral ischemia: Patho-physiologic mechanisms and rationale for future avenues of treatment. Mayo Clin Proc 62: 35-55, 1987

23) Moneada S, Palmer RMJ, Higgs EA: Nitric oxide, physiology, pathophysiology and pharmacology. Pharmacol Rev 43: 109-142, 1991

24) Myers PR, Minor RL, Gueria R, Bates JN, Harrison DG: Vasorelaxant properties of the endothelium derived relaxing factor more closely resemble $\mathrm{S}$ nitrosocysteine than nitric oxide. Nature 345: 161164,1990

25) Nelson CW, Wei EP, Povlishock JT, Kontos HA, Moskowitz MA: Oxygen radicals in cerebral ischemia. Am J Physiol 263: H1356-H1362, 1992

26) Nishizuka $Y$ : The role of protein kinase $C$ in cell surface signal transduction and tumour promotion. Nature 308: 693-698, 1984

27) Oh SM, Betz AL: Interaction between free radicals and excitatory amino acids in formation of ischemic brain edema in rats. Stroke 22: 915-921, 1991

28) Onodera $\mathrm{H}$, Araki $\mathrm{T}$, Kogure $\mathrm{K}$ : Protein kinase $\mathrm{C}$ activity in the rat hippocampus after forebrain ischemia: Autoradiographic analysis by $\left[{ }^{3} \mathrm{H}\right]$ phorbol 12,13-dibutyrate. Brain Res 481: 1-7, 1989

29) Osborne KA, Shigeno T, Balarsky AM, Ford I, McCulloch J, Teasdale GM, Graham DI: Quantitative assessment of early brain damage in a rat model of focal cerebral ischemia. $J$ Neurol Neurosurg Psychiatry 50: 402-410, 1987

30) Pellegrini-Giampietro DE, Cherici G, Alesiani M,
Carla V, Moroni F: Excitatory amino acid release from rat hippocampal slices as a consequence of freeradical formation. $J$ Neurochem 51: 1960-1963, 1988

31) Pellegrini-Giampietro DE, Cherici G, Alesiani $M$, Carla V, Moroni F: Excitatory amino acid release and free radical formation may cooperate in the genesis of ischemia-induced neuronal damage. $J$ Neurosci 10: 1035-1041, 1990

32) Perkins WJ, Milde LN, Milde JH, Michenfelder JD: Pretreatment with U74006F improves neurologic outcome following complete cerebral ischemia in dogs. Stroke 22: 902-909, 1991

33) Rubanyi GM, Vanhoutte PM: Oxygen-derived free radicals, endothelium, and responsiveness of vascular smooth muscle. Am $J$ Physiol 250: H815H821, 1986

34) Rubanyi GM, Vanhoutte PM: Superoxide anions and hyperoxia inactivate endothelium-derived relaxing factor. Am J Physiol 250: H822-H827, 1986

35) Sakurada O, Kennedy C, Jehle J, Brown JD, Carbin GL, Sokoloff L: Measurement of local cerebral blood flow with ${ }^{14} \mathrm{C}$-iodoantipyrine. Am $J$ Physiol 234: H59-H66, 1978

36) Schmidley JW: Free radicals in central nervous system ischemia. Stroke 21: 1086-1090, 1990

37) Siesjö BK, Agardh CD, Bengtsson F: Free Radicals and Brain Damage, Cerebrovascular and Brain Metabolism Reviews 1. New York, Raven Press, 1989, pp 165-211

38) Stehbens WE: Blood vessel changes in chronic experimental arteriovenous fistulas. Surg Gynec Obstet 127: 327-338, 1968

39) Stehbens WE: Hemodynamic production of lipid deposition, intimal tears, mural dissection and thrombosis in the blood vessel wall. Proc R Soc Lond [Biol] 185: 357-373, 1974

40) Sugawa M, Koide $T$, Naitoh $S$, Takato $M$, Matsui $T$, Asano T: Phorbol 12,13-diacetate induced contraction of the canine basilar artery: Role of protein kinase C. $J$ Cereb Blood Flow Metab 11: 135-142, 1991

41) Tamura A, Graham DI, McCulloch J, Teasdale GM: Focal cerebral ischemia in the rat: 1. Description of technique and early neuropathological consequences following middle cerebral artery occlusion. $J$ Cereb Blood Flow Metab 1: 53-60, 1981

42) Ueda T, Yamamoto YL, Diksic M: Transvenous perfusion of the brain with verapamil during focal cerebral ischemia. Stroke 20: 501-506, 1989

43) Ueda T, Yamamoto YL, Takara E, Diksic M: Tolerance of the cerebral venous system to retrograde perfusion pressure in focal cerebral ischemia in rats. Stroke 20: 378-385, 1989

44) Worley PF, Baraban JM, Snyder SH: Heterogeneous localization of protein kinase $\mathrm{C}$ in rat brain: Autoradiographic analysis of phorbol ester receptor binding. $J$ Neurosci 6: 199-207, 1986

45) Yamamoto $M$, Shima $T$, Uozumi $T$, Sogabe $T$, Yamada $\mathrm{K}$, Kawasaki $\mathrm{T}$ : A possible role of lipid 
peroxidation in cellular damages caused by cerebral ischemia and the protective effect of $\alpha$-tocopherol administration. Stroke 14: 977-982, 1983

46) Yamamoto $Y L$, Ueda $T$, Shimauchi M, Diksic M: Efficacy of bypass between extracerebral artery and cerebral vein with retrograde verapamil infusion into focal cerebral ischemic tissue in rats. Neurosurgery 29: 719-726, 1991
Address reprint requests to: T. Nagao, M.D., Department of Neurosurgery, Neurological Institute, Tokyo Women's Medical College, 8-1 Kawada-cho, Shinjuku-ku, Tokyo 162, Japan. 